\title{
LEGAL CULTURE AS AN ELEMENT OF MANAGEMENT ACTIVITY IN LOCAL GOVERNMENT BODIES IN UKRAINE
}

\author{
K.O. YEMELIANENKO, PhD (Law), \\ Senior Lecturer of Department of Theory and History of State and Law, \\ National University of Life and Environmental Sciences of Ukraine \\ E-mail: karimkiev@ukr.net
}

Summary. The article examines the legal culture as a necessary element in the management activities carried out by local governments in Ukraine. The author analyzes the initiatives, preconditions and approaches to the proper use of legal culture in the activities of local governments, their impact on the legal culture of society, as well as the degree and quality of services guaranteed by fundamental human rights and freedoms by the state.

The author analyzes the concept of legal culture in relation to its practical application in the management of local self-government in terms of efficiency and use of opportunities for the development of territorial communities. It also emphasizes the new disposition of local self-government, when as a result of reforming the administrative-territorial structure of Ukraine, new territorial communities were formed, thus forming the basis of a new subregional level - new united districts; accordingly, the new territorial communities were given powers that were previously exercised by a network of local executive offices, and most importantly - their own financial and land resources. The author draws attention to the successful technical implementation of local government reform, and at the same time increasing the role of the value system in local self-government, in particular raising the level of legal culture and legal awareness in communities and in modern society as a whole.

Thus, according to the author of the article, it is based on the results of the formation of local authorities that the local elite is formed, which should contribute in every way to raising the legal culture and legal awareness of the population.

The author of the article substantially studies the modern theoretical origins of legal culture from its philosophical and legal characteristics to the legal culture of municipal management as a specific type of management culture in the legal culture of society, the value of legal culture in relation to society (or its parts) to management or management personnel.

The author also draws attention to the processes that take place depending on the level of legal culture and notes the views of other researchers of legal culture on the construction of possible internal confrontations among local elites.

In the conclusions, the author notes that the value of legal culture lies in certain modern methodological standards that should be introduced in such public authorities as local government, thus disseminating successful international practices, values and institutional experience.

Keywords: legal culture, legal culture of society, local governments, territorial communities, management activities 


\section{Introduction.}

The study of legal culture in the activities of local governments today remains one of the most important issues of socio-political and legal life of Ukrainian society.

Since the completion of the next stage of reforming the administrative-territorial structure of Ukraine, along with the last regular local elections, new local councils such as united territorial communities of cities, villages and settlementshave been formed; new subregional administrative formations such as new districts were formed also.

Through these processes, there are quite clearly displayed in society the level of development of legal consciousness of citizens, application of new election legislation, compliance with law and order, degree of effectiveness of citizens' exercise of their suffrage, features of solving conflict situationsthrough application of legal and socially necessary values in formation and functioning of local governments as institutions of public power etc.

\section{Analysis of recent researches and publications.}

Both contemporary native scientists and recognized specialists in this field, in particular: Averyanov V.B, Rabinovich P.M, Kuybida V.S., Tolkovanov V.V, Kovbasyuk Yu.V., Vashchenko K.O., Pittsyk M.V., Pukhtynsky M.O., Seryogin S.M., Sergienko E.O., Lomachynska I.M., Logunova M.M., Kushnir M.O., Makarenko L.O., Kachur V.O. and others, as well as international research institutions and their representations in Ukraine were concerned with legal culture as an element of administrative activity in local self-government bodies.
The purpose is to study the application of legal culture in the management of local governments in Ukraine, its impact on the legal culture of the individual and the level of legal culture of society in Ukraine as a whole.

\section{Results.}

In modern conditions of reorganization of the system of local self-government bodies, with the next formation of public authoritiesnew tendencies of development of legal culture at the corresponding levels of their formation are formed and introduced, organizational bases for acceptance of important public decisions are formed also. This can be observed in the formation of local power elites, who won the election and defend the rights of their constituents, form the level of legal culture of the community - in the city, town or village.

Every time, waiting for the changes in local elites in Ukraine, science and society pay more and more attention to the value orientations that were characteristic of several generations of Ukrainians, universal human values, political and cultural traditions, and state and legal guidelines.

At the same time, in recent years the level of legal culture has been greatly influenced by public policy as well as various authoritative international organizations, which aimed to promote legal culture, civic activity, legal awareness in society, legal science by increasing the role of the value system in Ukraine. In particular, the relevant bylaws improved the motivational base of government officials, local government officials, formed a new corporate culture, which in turn created a solid foundation for the modernization of the entire system of public administration and local self-government, in particular. 
Today, the study of legal culture is not limited to the legal consciousness of citizens, but is defined as a set of achievements of society, its social groups and citizens in regulating social relations, which is ensured by the rule of law in public life, legal principles of justice and humanism, protection of human rights and freedoms, human honor and dignity, the real security of the human place as the highest social value (Popadynets, 2014: 124).

According to the philosophical and legal characteristics of the scientist-lawyer Alekseev S.S., legal culture, in his opinion, is «legal wealth, which is expressed in the achieved level of development of regulatory qualities of law, accumulated legal values, those features of law, legal techniques that belong to spiritual culture, to legal progress, because legal culture really expresses the social value of law, legal progress» (Alekseev, 1999: 237).

According to the well-known Ukrainian lawyer Rabinovych P.M., legal culture is closely interconnected by common human culture, because legal culture is a general state of «legal affairs» in society, the state of legislation and the function of the court, all law enforcement bodies, legal awareness of the entire population, which expresses the level of development of law and legal awareness, their place in society, the assimilation of legal values, their implementation in practice, the implementation of the requirements of the rule of law (Rabynovych, 2005: 5).

The famous Ukrainian researcher Kachur V.O. (Kachur, 2019: 16) defines culture as a specific way of organizing and developing human life in specific historical conditions which determines the social orientation and life position of participants in public life and manifests itself in public values. And she considers legal culture as one of the varieties of general culture, which constitutes its separate section, is a synthesis of law and culture, and is also characterized by some autonomy to other types of culture (material, economic, political, etc.)

Analyzing the concept of «legal culture» in management activities, scientists reveal other scientific visions. According to Yakushev A.V., «legal culture is the quality of legal life of society and the degree of state and society guarantee of human rights and freedoms, as well as knowledge, understanding and observance of law by each individual member of society» (Konstytutsyonnoe Pravo, 2000: 161). Domestic researcher Pisarenko Zh. A. emphasizes that managerial culture, which combines elements of general culture with the peculiarities of management activities, can be studied as a system consisting of values, norms of morality and ethics, managerial knowledge and skills.

Management culture, in addition to managerial knowledge, skills and abilities, includes a set of material and spiritual achievements obtained in the process of making and implementing management decisions. Thus, the culture of management is a system of theoretical and practical provisions, principles and norms that are general in nature and apply equally to all aspects of human activity (Pysarenko, 2009: 44).

One of the features of the study of the legal culture of local government officials is that scholars consider it as a conditional factor of coherence and stable activity as public authorities, which accordingly affects the efficiency and quality of the functioning of these bodies.

Thus, scientists (Pysarenko, 2008: 380 ) identified the concept of «professional legal culture of officials», which 
can be defined as a kind of realization of legal consciousness, which includes a set of ideas, feelings, feelings that reflect the attitude to law and personal belief in its effectiveness as a means of regulating social relations between citizens and public authorities.

Taking into the account the peculiarities of management of local governments (complexity of tasks, requirements for the priority of local and regional development, rational decisions, competence and professionalism of officials and officials of local government), some scientists and researchers (Serhiienko, 2008: 177) consider the culture of municipal government as a specific type of management culture, which is more regulated, because the activities of local governments and their officials are always limited by laws and regulations, community statutes.

As the scientist Lyubchenko P.M. («Formuvannia Ta Rozvytok Pravovoi Kultury...») defines, the legal culture of officials oflocal government is an integral part of the general legal culture of society, which is based on the same principles and is a reflection of its level of development. There can be no high level of legal culture of local government if the general level of legal culture of society is low. The formation of the legal culture of local government officials is not a separate process, for its development other types of culture are important - political, moral and aesthetic.

Undoubtedly, Ukraine as a new state from the first years of its birth tried to «turn» unacceptable social values into a new - state system. However, the change in the socio-political system in the new state led to the destruction of a stable system of values that were characteristic of several generations of Ukrainians. Thus, the new Ukrainian society, not having time to transform, significantly broke away from the original socio-historical landmarks and cultural traditions. Legal culture began to lose its original value for society, and public interests became narrowly consumer.

Of course, unde $\mathrm{r}$ such conditions, most people feel life disorientation, fear of the future, uncertainty, insecurity, general lack of confidence in society, lack of confid e nce of public authorities and local governments, which controlled, regu lated public relations and acted as a guarantor of stable development of the country.

It is appropriate to pay attention to the comment of the researcher of legal values and legal culture Makeeva O.M. (Makeiev a, $2015:$ 263), which notes that in modern Ukrainian society there are more and $m$ ore manifestations of disrespect for laws, legal norms, government agencies and officials. This is primarily due to the fact that in modern conditions in the consciousnessof people the authority of law and the state is reduced. This is facilitated by events related to the confrontation between different states, authorities and representatives of big business, branches of government, government and civil society. As a result, there is no clear system and program of action for the functioning of the entire economic, political and legal system of society; program of legal education of society.

As you know, the Ukrainian legal system focu s es on European values, aimed at building a world of justice based on the principle of integrity of human dignity. The basis of such popularity of European values is that the most import ant value of Europe an society has become human dignity, human as a person and an individual. According to European standards, a society as close 
as possible to the ideal is one in which approp riate conditions are created that should provide all citizens with equal opportunities for development and use of their potential abilities, achievement of private and public goals as conditions for realization of the most important need (Makeieva, 2015: 264).

That is, the value of legal culture lies in certain methodological standards that can be applied in a given society, including in such public auth orities as local government. As for the legal culture of organizations, in the modern sense we mean «corp orate culture», that are the customs and traditions of employees of a certain field of activity, but the modern content of the legal culture of public authorities and local governments in recent years has been significantly modified by means of European and world institutions and donor organizations, mainly in terms of values and institutions.

Accor ding to some res earchers (Kame ron, 2001: 179), organizational culture is a system of norms and values chara cteristic of a particular organization. Org anizat i ona 1 culture is determined by a set of values, concepts, expectations, views, norms inherent only in its philosophy and includes the following components: regulators of behavior (organizational rituals, ceremonies, langu age); key inte rnal organizational values shared by most members of the organization; a specific philosophy that determines the relationship between employees and customers; unwritten rules for e sta b lishing relationships between members of the organization; the image of the organization, which is formed by the behavior of employees in the external environment, etc.

Ukraini an scientist Sergienko E.A. defin es the co nce pt of «organizational culture of municipal government» as adapted to the conditions of municipal government set of social values and ideas, norms of professional public administration behavior, derived from awareness of the mission of municipal government, based on the orientation of all activities on client-citizen, determine the ability of staff to change and transform the governing body into an «enterprise» for the provision of quality services to the population (Serhiienko, 2009: 363).

Accor ding to s ome scientists and resea rchers (M ahura, 2002: 26), (Permiakova, 2012: 83), the organizational culture of a public authority is a system of values, principles, norms and rules of behavior formed in a particular public authority and shared by its employees, which determines both internal relations and the relationship of public authority with the external environment. With the help of org ani zational culture, models and rules of organizational behavior are determined, a certain climate in the team is formed, coordination and control of employees' activities is carried out, a system of motivation is created, and so on.

World experience shows that on a corporate basis through motivated forms of public participation in management is achieved mo re effective interaction betwe en gov ernment, community and business. Thus, we can conclude that corporate culture to occupies a higher level compared to organizational culture, and also plays a more important role in modernizing the municipal governance system.

In particular, the Ukrainian researcher Sidorenko N.S. in her scientific research, paid considerable attention to the study of the phenomenon of «professional culture of the employee» (Sydorenko, 2009: 264), which can be defined as a systemic qualitative state of personality, which characterizes the level of socio-profes- 
sional development of civil servants, the extent and manner of realization of its essential strengths and creative activity in the form of values, norms, style of thinking, motivation, professional and cultural competence, personal qualities in the process of professional activity and its results. While the Ukrainian researcher Pisarenko Zh.A. emphasizes that «managerial culture, which combines elements of general culture with the peculiarities of managerial activity, can be considered as a system consisting of values, norms of morality and ethics, managerial knowledge and skills. Management culture, in addition to managerial knowledge, skills and abilities, includes a set of material and spiritu al achievements obtained in the process of making and implementing management decisions. Thus, the culture of management is a system of theoretical and practic al provisions, principles and norms that are general in nature and apply equally to all aspects of human activity» (Pysarenko, 2007: 122).

All this suggests that mastering the culture of work for civil servants and local government officials means learning to work responsibly and creatively under the conditions of mandatory implementation of the principles of public service, which will promote self-realization, harmonization in internal organizational relations and relations with other citizens. Thus, we can agree with the opinion of some resear chers (Koltun, 2001: 181), (Loma chynsk a, 2005: 134) on the relationship between the work culture of local g overnm ent officials and municipal culture and the culture of municipal government, namely: the work culture of civil servants and local government officials is the basis of municipal culture, which most scientists consider one of the most important preconditions for successful local government reform in Ukraine.

\section{Conclusions and prospects.}

Most local government officials carry out their activities, which are related in one way or another to management activities. Therefore, in order to perform his / her official duties, a specific local government official must have the appropriate knowledge, skills and qualities, which are determined not only by the normative act, but also by the personal values of legal culture as a component of management. Therefore, local governments, which are called to perform managerial, regulatory, representative and other functions, are responsible to the community for the level and quality of public services and services for citizens and residents of the community. And in turn, exactly through the legal culture of a local government official, as a necessary element of management, the necessary effective connection of a community resident as a consumer of public serv ices with the local represe ntative body of government is formed.

Thus, the application of legal culture in the management of local governments in Ukraine has a huge impact on the legal culture of the individual of each inhabitant of a community and the level of legal culture of society in Ukraine as a whole.

\section{References}

1. P opadynets, H.O. (2014). Pravova Kultura Yak Vazhlyvyi Element Pravovoi Systemy Ukra iny. Visnyk Natsionalnoho Universytetu Lviska Politekhnika. Seriia Yurydychni Nauky, 782: 123-128 (in Ukrainian).

2. Alekseev, S.S. (1999). Pravo. Azbuka-Teoryia-Fylosofyia. Opyt Kompleksnoho Yssledovanyia. Moskva: Statut, 712 (in Russian).

3. Rabynovych, P.M. (2005). Osnovy Obshchei Teoryy Prava Y Hosudarstva. Kharkov: Konsum, 320 (in Russian). 
4. Kachur, V.O. (2019). Do Vyznachennia Poniattia Pravova Kultura U Pravovznastvi. Law.Human. Environment, 10(1): 261-264 (in Ukrainian).

5. K onstytutsyonnoe Pravo Zarubezhnykh Stran: Kurs Lektsyi. Yakushev (2000). Moskva, 336 (in Russian).

6. P ysarenko, Zh.A. (2009). Orhanizatsiino-P ravovi Zasady Rozvytku Kultury Derzhavnoho Upravlinnia V Ukraini. Derzhavne Budivnytstvo (in Ukrainian).

7. Pysarenko, Zh.A. (2008). Orhanizatsiina Kultura Yak Chynnyk Efektyvnosti Upravlinnia Pers onalom U Derzhavnykh Orhanakh. Naukovyi Visnyk Poltavskoho Universytetu Spoz hyvchoi Kooperatsii Ukrainy. U 2 ch. Poltava, 3 (30), 2: 379-380 (in Ukrainian).

8. S erhiienko, E. (2008). Priorytety Transformats ii Orhanizatsiinoi Kultury V Orhanakh Mist sevoho Samovriaduvannia. Teoriia Ta Praktyka Derzhavnoi Sluzhby: materialy Konfere ntsii (Dnipropetrovsk, 19-20.09.2008). Dnipropetrovsk, 176-178 (in Ukrainian).

9. Formuvannia Ta Rozvytok Pravovoi Kultury Kadr iv Mistsevoho Samovriaduvannia V Ukra ini. Available at : http://dspace.nlu. edu. ua/bitstream/123456789/14340/1/ Lubchenko_98-100.pdf (in Ukrainian)

10. Makeieva, O.M. (2015). Pravova Kultura Tsinnisnyi Vymir V Umovakh Intehratsiinykh Protsesiv. Almanah Prava, 6: 261-264 (in Ukrainian).

11. Kameron, K. (2001). Dyahnostyka Y Yzmenenye Orhanyzatsyonnoi Kultury. Sankt-Pe- terburg: Piter, 320 (in Russian).

12. Serhiienko, Ye.O. (2009). Orhanizatsiina Kult ura V Publichnomu Upravlinni Terminolohichni Problemy. Efektyvnist Derzhavnoho Upravlinnia Zbirnyk Prats. Lviv, 18/19: 361-367 (in Ukrainian).

13. Mahura, M.Y. (2002). Orhanyzatsyonnaia Kult ura Kak Sredstvo Uspeshnoi Realyzatsyy Orhanyzatsyonnykh Yzmenenyi. Upravlenye Personalom, 1: 24-29 (in Russian).

14. Permiakova, L.D. (2012). Orhanizatsiina Kultura Orhanu Publichnoi Vlady Yak Obiekt Upravlinnia. Derzhava Ta Rehiony.Seriia Derzhavne Upravlinnia, 3(39): 80-85 (in Ukrainian).

15. Sydorenko, N.S. (2009). Kompetentnisnyi Pidkhid Do Otsiniuvannia Profesiinoi Kultury Kadr iv Derzhavnoho Upravlinnia. Aktualni Problemy Derzhavnoho Upravlinnia: zbirnyk nauk ovyh prats. Dnipropetrovsk: DRIDU NADU, 1(35): 259-267 (in Ukrainian).

16. Pysarenko, Zh.A. (2007). Struktura Kultury Derz havnoho Upravlinnia: Teoretyko-Metodol ohichnyi Aspekt. Teoriia Ta Praktyka Derzhavnoho Upravlinnia. Kharkiv: Mahistr, 1(16): 119-125 (in Ukrainian).

17. Koltun, V.S. (2001). Etyka I Efektyvnist U Derzhavnii Sluzhbi. Zbirnyk naukovyh prats. za red. V.I., Lugovogo, V.M., Knyazeva. Kyiv: vydavnytstvo UADU, 1: 180-192 (in Ukrainian).

18. Lomachynska, I.M. (2005). Profesiina Etyka. Kyiv, 226 (in Ukrainian).

\section{К.О. ЄМЕЛЬЯНЕНКО (2021). ПРАВОВА КУЛЬТУРА ЯК ЕЛЕМЕНТ УПРАВЛІНСЬКОЇ ДІЯЛЬНОСТІ В ОРГАНАХ МІСЦЕВОГО САМОВРЯДУВАННЯ В УКРАЇНІ. ПраВО.}

Людина. Довкілля, 12(1): 12-19. https://doi.org/10.31548/law2021.01.002.

Анотація. В статті досліджено правову культуру як необхідний елемент в управлінській діяльності, що здійснюється органами місцевого самоврядування в Україні. Проаналізовано ініціативи, передумови та підходи щодо належного використання правової культури в діяльності органів місцевого самоврядування, їх вплив на правову культуру суспільства, а також ступінь та якість надання послуг і сервісів, що гарантуються через основні права і свободи людини державою. Автором аналізується поняття правової культури щодо його практичного застосування в управлінській діяльності місцевого самоврядування в аспекті ефективності та використанні можливостей для розвитку

18 | ISSN 2663-1350 «ПРАВО. ЛЮДИНА. ДОВКІЛЛЯ» | «LAW. HUMAN. ENVIRONMENT»

Vol. 12, № 1, 2021 
територіальних громад. Також наголошується на новій диспозиції місцевого самоврядування, коли в результаті реформування адміністративно-територіального устрою Укра їни утворились нові територіальні громади, склавши тим самим основу нового субрегіонального рівня - нових об'єднаних районів; відповідно новим територіальним громадам було передано повноваження, які раніше здійснювались мережею представництв органів виконавчої влади на місцях, і головне - власний фінансовий та земельний ресурс. Автор звертає увагу на успішну технічну реалізацію реформування місцевого самоврядування, а разом з тим і підвищення ролі системи цінностей в місцевому само врядуванні, зокрема підвищення рівня правової культури і правосвідомості як в громадах так і в сучасному суспільстві загалом. Так, на думку автора статті, саме за результатами формування органів місцевої влади формується і місцева еліта, що має всіляко сприяти підвищенню правової культури та правової обізнаності населення. Автором статті змістовно досліджено сучасні теоретичні витоки правової культури від іï фрілософрько-правових характеристик до розгляду правової культури муніципального управління як специфічного виду культури управління в правовій культурі суспільства, цінності правової культури по відношенню суспільства (чи його окремих частин) до органів управління чи окремих управлінських кадрів. Також автором звертається увага на процеси, що відбуваються залежно від рівня правової культури та відзначаються думки інших дослідників правової культури, щодо конструювання можливих внутрішніх протист оянь серед місцевих еліт. У висновках автором зазначено, що чінність правової культури полягає у певних сучасних методологічних стандартах, які слід запроваджувати в таких публічних органах влади як місцеве самоврядування, поширюючи тим самим успішні міжнародні практики, ціннісний та інституційний досвід.

Ключові слова: правова культура, правова культура суспільства, органи місцевого самоврядування, територіальні громади, управлінська діяльність 